\title{
WORK AS A CENTRAL LIFE INTEREST FOR LEGAL PROFESSIONALS
}

\author{
JACQUES GENIS \\ TARYN WALLIS \\ Section of Organisational Psychology \\ School of Management Studies \\ University of Cape Town
}

\begin{abstract}
Dubin's theory of Central Life Interests (CLIs) was used to investigate whether work is a CLI for legal professionals in South Africa. The research also served as a comparative exploration between the public and private sectors based on their work centrality and work orientation. 59 employees from three public sector organisations and 27 employees from various private sector law firms completed questionnaires. Contrary to Dubin's theory, results indicated that two-thirds of respondents did not have work as a CLI. Also, contrary to previous work on private and public sector employees, some interesting similarities emerged between the two sectors.
\end{abstract}

\section{OPSOMMING}

Dubin (1992) se teorie van Sentrale Lewensbelangstellings was gebruik om te ondersoek of werk 'n sentrale lewensbelangstelling is vir individue in die Suid-Afrikaanse regsprofessie. Die navorsing was ook 'n vergelykende ondersoek tussen die publieke en privaat sektore met betrekking tot hul werk sentraliteit en werk orientasie. 59 werknemers van drie publieke organisasies en 27 werknemers van verskeie privaat firmas het vraelyse beantwoord. Teenstellig met Dubin se teorie het resultate gewys dat vir twee-derdes van die deelnemers werk nie 'n sentrale lewensbelangstelling was nie. Daar was ook interessante resultate wat te voorskyn gekom het, wat teenstrydig was met vorige navorsing op werknemers in die privaat en publieke sektore.

The 1960s and 1970s saw a significant amount of research done on the construct of Central Life Interests (CLIs), initially introduced and developed by Dubin (1956). By the 1980s, though, this research had begun to wane. Now, however, changes to the concept of a 'career' have led to a resurgence of research on attitudes towards work (Aronowitz \& DiFazio, 1994; Bridges, 1994; Rifkin, 1995; Schreuder \& Theron, 2001; M. Wallace, 1989). These changes have also resulted in the occupational structure becoming heavily skewed in favour of high-status, professional, knowledge workers (Rifkin; Schreuder \& Theron; M. Wallace). Thus it becomes increasingly important to investigate what effects these changes will have on the importance and centrality of work in the lives of professionals. The research described in this article was therefore conducted with the aim of contributing to updating the CLI literature, particularly with respect to professionals, since much of the currently available information reflects old research. This study therefore specifically aimed to investigate whether work is considered a CLI by legal professionals in South Africa and to consider the impact of work centrality on the work orientation of legal professionals. With respect to both of these aims, differences between public and private sector legal professionals were explored.

\section{The meaning of work}

Defining work is not an easy task and the boundaries that define work are not clear-cut (Brief \& Nord, 1990; Noon \& Blyton, 1997; Watson, 1995). For example, sometimes the same activity may represent a leisure activity in one context and work in another (Brief \& Nord; Noon \& Blyton). It is therefore not the activity itself that defines whether or not it is work, but the consequences of, and circumstances under which, the activity is undertaken

Most contemporary writers employ the economic definition of work (Aronowitz \& DiFazio, 1994; Brief \& Nord, 1990; Noon \& Blyton, 1997; Watson, 1995). For example, Watson defined work as "the carrying out of tasks which enable people to make a living within the environment in which

Requests for copies should be addressed to: T Wallis, Section of Organisational Psychology, School of Management Studies, University of Cape Town, Private Bag Rondebosch, 7700 they find themselves" (p.113), and Brief and Nord defined work as "an activity for which one receives financial remuneration" (p. 11). However, this economic definition of work is not without its problems (Brief \& Nord; Noon \& Blyton). The concentration solely on paid work ignores huge areas of unpaid or "hidden" work (Noon \& Blyton, p.9), usually household-based (for example cooking, cleaning, child rearing or home improvements) or voluntary work (Brief \& Nord; Noon \& Blyton). It is important to recognise the serious problems involved with the conventional economic definition, yet it is what the word appears to mean most often when it is used at the present time (Brief \& Nord; Dubin, 1992; Noon \& Blyton; Watson).

Individuals who subscribe to an economic definition of work are often said to have an extrinsic work orientation. Such individuals view work in terms of its instrumental nature, in that it provides a means to obtain valued outcomes that are not themselves work centred (Roberson, 1990; Watson, 1995). In contrast, individuals with an intrinsic work orientation believe that work itself results in desired outcomes (Roberson; Watson). The actual content and substance of work are viewed as important sources of reward, because it is directly enjoyable in itself or because it provides opportunity for achievement and recognition (Argyle, 1972; Roberson). In this view, work is considered a major component of an individual's identity (Argyle; Aronowitz \& DiFazio, 1994; Noon \& Blyton, 1997; Watson). This is because work, employment and careers give individuals a sense of who they are and give meaning to their lives (Argyle).

It was research on work orientation that led to research on work as a CLI (often referred to as work centrality) (Roberson, 1990). Dubin's (1956) research remains seminal in this area, and this is discussed further in the next section.

\section{The concept of work centrality}

A Central Life Interest was operationally defined as the expressed preference for a given situation in carrying out an activity (Dubin, 1956). However, Dubin's definition of a Central Life Interest has been revised and is now defined as "that portion of a person's total life in which energies are 
invested in both physical and intellectual activities and in positive emotional states" (Dubin, 1992, p.41). Research on CLIs has revealed the following aspects (Dubin, 1992): Firstly, the choice of CLI is a conscious decision, made when evaluating the satisfactions enjoyed while pursuing it; secondly, individuals control whether they invest energy in a specific situation or not; and, thirdly, the amount of physical and emotional energy invested reflects the importance or centrality of that activity.

The centrality concept refers to the value of outcomes available at work relative to those available or sought from other social roles (Roberson, 1990). Individuals for whom work is a CLI believe that their most highly valued outcomes are available in the work setting and thus they display a tendency to view the work environment as their preferred social setting (Bryan, 1972; Dubin, 1956; Roberson). In general, work has been found to be of relatively high importance as compared with other areas of life (Friedlander, 1966; Snir \& Harpaz, 2001, as cited in Vigoda, 2002). It is usually considered to be of more importance than leisure and recreation, education and church-related matters (Friedlander) and in several studies was found to be ranked second only to family (e.g. Snir \& Harpaz, as cited in Vigoda; Wallis \& Price, 2003)

Results of research studies suggest, however, that considerable variation exists regarding how various occupational groups perceive their world of work. A fair amount of research has found that work is not a CLI for the majority of working individuals (Bryan, 1972; Dubin, 1956; Dubin, Champoux \& Porter, 1975). This finding is most applicable to industrial workers in general, and a number of studies have established that among those below managerial and supervisory ranks in commerce and industry, only about a third consider their work to be a CLI (Dubin, 1956, 1992; Dubin, Champoux \& Porter). In contrast to these results, members of occupations that can be classified as professional, tend as a group to view their work as a CLI (Bryan; Dubin, 1992; Friedlander, 1966; Orzack, 1959). Studies have shown that the overwhelming proportion of professionals invest their emotional energy in their work (Dubin, 1992).

It has been argued that there are various general factors in the nature of professional work that could account for this phenomenon (Bryan, 1972; Dubin, 1992; Orzack, 1959). Professional work generally allows individuals autonomy to decide how to do certain tasks, it allows them to use creativity and initiative to complete activities at work and it involves personal responsibility for outcomes of performance (Dubin). Another central feature of professional performance is that it always entails some degree of uncertainty or risk (Dubin). Their specialized and prolonged training allows them to minimize the risk and uncertainty involved and also encourages the development of a commitment to work and to their professional community (Orzack). Also, along with professionalism, typically, comes an amount of status that would result in a greater acceptance of work as a CLI compared to low level, unskilled or semi-skilled work (Orzack).

\section{The Relationship between work centrality and work orientation}

It has been found that individuals with work as a CLI tend to have an intrinsic work orientation, preferring jobs containing challenge, freedom, participation, and personal growth instead of jobs characterized by friendly relationships with coworkers and management, high salary, and job security (Rabinowitz \& Hall, 1980, as cited in Roberson, 1990). Individuals who view work as their CLI have also been shown to value outcomes that reflect high investment in the job such as challenge and responsibility. In contrast, those individuals who do not have work as their CLI have been shown to have more extrinsic work orientations, valuing outcomes concerned with withdrawal from the workplace, such as short hours, holidays and vacations (Dubin, Hedley \& Taveggia, 1976, as cited in Roberson).

Despite these studies, others have found no relationship between work orientation and work centrality (e.g. Gorn \& Kanungo, 1980; Starcevich, 1973), and these contradictory findings suggest that more research might be needed to come to a conclusion on the matter. These contradictions served as a further rationale for the current investigation of legal professionals into the relationship between their work centrality and work orientation. A review of the literature also found that there has been limited recent research done on work as a CLI for professionals. A study by Baba (1989) explored the relationship between CLI and job involvement among professional teachers in Nigeria and Trinidad, and found a significant positive relationship between CLI in work and job involvement in both cultures. Apart from this study, however there are virtually no studies done on work centrality in the developing world (Baba). These discoveries highlighted the necessity of the current research in contributing to the understanding of CLI for professionals, especially in a developing country such as South Africa.

\section{METHOD}

\section{Participants}

The data for the study was obtained from 86 legal professionals in the Western Cape, 27 from various private law firms and 59 from the public sector. The legal profession is very diversified when it comes to possible occupational groupings (Doyle, 2001; Human, 1998) - the three biggest occupational groups in a total of 12 identified, were lawyers, claims handlers and advocates. In terms of gender, $45 \%$ of the sample was female and $55 \%$ male. Just over half $(57 \%)$ of the sample was either married or living with a partner while $38 \%$ of the sample had children living at home. The average age was 32 years, while the average time spent working in the legal profession was 5.9 years. The average number of hours worked per week (including overtime) was 42.5 .

\section{Measuring Instrument}

The data collection technique consisted of a fourpart questionnaire. Section A of the questionnaire consisted of questions related to demographic information. Here, the demographic data collected focused on those variables that have been found to affect choice of CLI, such as gender and the presence of children in the home. Section B contained the original 40-item Central Life Interest Scale developed by Dubin (1956). This scale was checked to ensure that the language was up-to-date and understandable. Since legal professionals possess a good understanding of the English language, it was felt that the scale would not present undue difficulties in this regard. The items in the CLI scale deal with membership in formal organisations, technological aspects of the environment, informal personal relationships, and general everyday experiences. A respondent is presented with a specific behaviour and three alternative settings for the occurrence of the behaviour. One alternative specifies the work setting, another specifies some setting away from work, and the third indicates no preference as to the setting of the behaviour. Dubin's scoring method was used to categorise participants as either having work as a CLI or not.

Studies have established concurrent-, convergent-, and discriminant validity for the CLI Scale (Dalton \& Todor, 1983, Dubin \& Champoux, 1977; Dubin, Champoux \& Porter, 1975), and it has been widely used for measuring the construct of work centrality. Determining the internal consistency of the 
CLI scale has, however, presented a problem due to the fact that the items are not homogeneous. The scale is a heterogeneous classificatory instrument and thus low internal consistency would be expected (Dalton \& Todor). The best possible way to assess the reliability of scales such as this has been found to be test-retest reliability (Dalton \& Todor). There was, however, unfortunately no data available in the literature on the test-retest reliability of this particular scale. Due to time constraints and the availability of legal professionals in the present sample, a test-retest could not be done in the current study either.

Sections C and D of the questionnaire concerned general aspects of work life and the meaning of work, and consisted of items taken from the Meaning Of Work (MOW) Research Team Questionnaire, developed by England, Ruiz-Quintanilla and Maimer (1995). Not all items on the MOW Research Team Questionnaire were related to the constructs being tested and thus items were selected based on their applicability to assist in testing the constructs of work centrality and work orientation. The items varied from Likerttype responses to ordinal measurements asking respondents to assign points to illustrate their preference between work and other life interests.

\section{Procedure}

A combination of sampling techniques was used to obtain the participants for the research. For the selection of the public sector participants, three public organisations were contracted. The selections of the organisations were based on the size of their legal departments and the availability of the individuals who functioned within them. Once permission was given which allowed access, questionnaires were distributed randomly throughout the legal department of the organisation (Fink, 1995). However, in selecting private sector legal professionals, snowball sampling was used (Henry, 1990). This sampling technique was used based on the difficulty of finding available and willing participants, mainly due to the fact that the private legal sector is made up of predominantly small firms, which made access to and distribution of questionnaires very difficult.

In both sectors questionnaires were given to specific contact individuals within the different firms, and they ensured that the questionnaires were randomly distributed among employees of the firm. Time was given to the respondents to complete the questionnaire and afterwards the questionnaires were collected. The response time of the different organisations varied between three days to a month.

\section{Data Analysis}

Various descriptive statistics were calculated for the demographic variables and all relevant variables. After scoring the CLI scale, a basic frequency count revealed the number of respondents who had work as a CLI and those who did not. To test whether there were any statistical relationships between work centrality and certain related variables, Pearson Chi-square tests were used. T-tests for independent samples were used to test the differences between groups in the sample (such as CLI group) on variables of interest. Where the requirements for the t-test, such as a normal distribution and homogenous variances were not met, the non-parametric Mann-Whitney U-Test was used instead. All statistical tests were carried out at the $5 \%$ significance level.

\section{RESULTS}

Using Dubin's (1956) CLI questionnaire, only a third of the 86 legal professionals surveyed $(n=28)$ were classified as having work as a CLI. The majority of the sample $(67 \%, \mathrm{n}=58)$, however, did not have work as a CLI. This finding cut across demographic characteristics, in that there were no statistically significant relationships between work centrality and gender $(p=0,09)$, marital status $(p=0,05)$ or presence of children in the home $(p=0,41)$. It must be noted, however, that the relationship between work centrality and marital status is very nearly statistically significant. Similarly, there was no difference between those legal professionals working in the public sector and those in the private sector in terms of work centrality $(p=0,91)$.

Contrary to Dubin's (1992) theory, there were also no statistically significant relationships between CLI and the characteristics seen as central to professional work (autonomy $(\mathrm{p}=0,94)$, personal responsibility for outcomes $(\mathrm{p}=0,21)$, creativity $(\mathrm{p}=0,24)$, and a degree of uncertainty and risk $(p=0,06))$. There was also no relationship between work centrality and amount of effort (in terms of both physical and mental energy) put into work $(p=0,59)$, as well as no difference between participants who have work as a CLI and those who do not in terms of number of hours worked in a week $(p=0,12)$.

Despite the majority of the sample not expressing work as a CLI, work was still found to be of high importance relative to other life areas. It was considered more important than religion, leisure and community, and was ranked second only after family. When asked to distribute a total of 100 points between different life areas, the average score assigned to work was statistically significantly higher for those participants who have work as a CLI than for those who do not $(\mathrm{p}=0,01)$.

Most of the sample $(69 \%, \mathrm{n}=59)$ expressed an extrinsic orientation towards work. When asked to distribute a total of 100 points across six work-related factors (three intrinsic and three extrinsic), the average score assigned to the extrinsic factors was considerably higher than that allocated to the intrinsic factors. Participants were also required to rank eight statements, four representing an intrinsic work orientation and four an extrinsic work orientation. Here again, extrinsic factors, namely 'good salary' and 'good job security' were most frequently ranked in first and second place respectively. These were followed, in order, by, 'interesting work'; 'opportunity to learn'; 'good opportunity for promotion'; 'good interpersonal relationships'; 'a lot of autonomy'; and lastly 'convenient work hours'.

The extrinsic orientation persisted across the public and private sector legal professional in the sample $(\mathrm{p}=0,06)$. Interestingly, it was found that there were no statistically significant differences between the relative importance attributed to income between the public and private sector $(p=0,37)$. However, the private sector ranked it significantly more important to have autonomy in the work they do $(p=0,01)$.

In terms of the relationship between CLI and work orientation, there were no statistically significant differences between individuals who have work as a CLI and those who do not with regard to intrinsic work orientation $(\mathrm{p}=0,97)$ or extrinsic work orientation $(p=0,98)$. Thus, in general, there seems to be no difference between the work orientations of the two groups. It was found, though, that those with work as a CLI tended to attribute significantly lower average scores $(p=0,04)$ to 'opportunity to learn new things'.

In line with the abovementioned extrinsic orientation, most respondents employed the economic definition of work, with the most frequently chosen statement to define when an activity is considered work being 'if you get money for doing it'. There were no statistically significant differences in the way in which individuals who had work as a CLI and those who did not defined work $(p=0,89)$. 


\section{DISCUSSION}

Contrary to Dubin's theory (1992), that work should be a CLI for professionals, the findings of this research indicated that work did not constitute a CLI for this group of legal professionals. Dubin argued that it is the very nature of professional work that culminates in it becoming central in the lives of professionals in general. However, none of the characteristics mentioned by Dubin (namely, high levels of autonomy, personal responsibility, and uncertainty and risk) played a role in predicting the work centrality of legal professionals in this research.

Previous research on professional teachers (e.g. Bryan, 1972) may provide the answer to this seeming contradiction. Bryan found that the substantial majority (79\%) of teachers studied did not view their work as a CLI. One of the main factors argued to decrease the likelihood that a teacher's work would take a central role in their lives compared to other professionals, was the fact that teaching may not provide suitable opportunities to develop and maintain close personal relationships. This is because the greatest proportion of teachers' work time is spent within individual classrooms separated from other staff members (Bryan). Teaching is thus usually an activity done in relative isolation and teachers may have to go outside their world of work to get their interpersonal needs met.

The legal profession is faced with a similar situation to that of the teaching profession. It has been argued that, increasingly, legal professionals are being employed to work in small, subordinate departments within larger, bureaucratic organisations, often in the public sector (J. E. Wallace, 1995). Legal professionals within these organisations therefore form the minority of individuals employed. Rather than improving the opportunity for these professionals to form a variety of close interpersonal bonds with co-workers, this work situation has led to legal professionals feeling alienated and estranged from their employer and colleagues (Hodson \& Sullivan, 1985, as cited in J. E. Wallace). Even though individuals in private law firms were found to have closer interpersonal relationships with their employers and co-workers, the significantly smaller size of private firms compared to bureaucratic public organisations has also been found to inhibit the opportunity for these relationships to form (J. E. Wallace). The importance of interpersonal relationships has continually been found to be one of the most important aspects to employees in work (Noon \& Blyton, 1997; Statt, 1994). A lack of close interpersonal relationships at work could thus definitely be a contributing factor that might affect the centrality of work for individuals in the legal profession.

Another factor that might account for why work is not a CLI for legal professionals is the fact that the profession as a whole is described as moving toward increasing specialisation in an effort to survive (Nelson, 1988, as cited in J. E. Wallace, 1995). It has been argued that the move towards increasing specialisation marks the deskilling and routinisation of professional work tasks (J. E. Wallace). Legal professionals that are highly specialised by field may only practice one type of law (e.g. real estate or tax law) and, within a given field of law, lawyers may also perform a limited variety of specialised legal tasks (e.g. drafting documents, litigation, giving legal advice and drafting opinions) (Doyle, 2001; Human, 1998; J. E. Wallace). This increasing level of routinisation can therefore impact on the level of centrality that work occupies in the legal profession.

Even though work was not found to be central in the lives of legal professionals, it was still found to play an important role, and was rated second only after family. This is consistent with most research findings (e.g. Friedlander, 1966; England \& Misumi, 1986), which found that work constitutes an integral part of any individual's life.
There is often a perception that there is a distinction between employees in the public and private sector. However, very few studies have focused on comparing work centrality between these two sectors, and those conducted have presented differing findings. One such comparative study on the legal profession found that legal professionals working in public organisations are significantly less committed to the profession than those working in private organisations (J. E. Wallace, 1995), whereas another found that there were no differences between the private and public sector employees concerning work centrality, and that these similarities remained stable over a period of 12 years (Snir \& Harpaz, 2001, as cited in Vigoda, 2002). In line with the latter study, the current research found that there was no difference between the public and private sector concerning work centrality. It should however be noted that the discrepancy in sample size between the public and private sector in the current sample might have contributed to the similarities that resulted.

The research findings seem to support the classical assumption that the main reason why individuals work is to earn money. A large pool of research (e.g. Watson, 1995) supports this assumption about employees' work orientation. However, an increasing amount of research has also provided evidence to suggest that it is not enough to argue that people merely work for extrinsic rewards (e.g. MOW International Research Team, 1987, as cited in Noon \& Blyton, 1997; Vecchio, 1980; Weaver \& Franz, 1992). This was found to be especially true concerning professionals (Noon \& Blyton; J. E. Wallace, 1995).

Thus the current findings that indicate that legal professionals have a predominantly extrinsic motivation towards work stands in direct contrast to this body of previous research. There are certain factors that could account for this. The drastic changes in the economic, social and technological world of work over the last two decades have definitely had a major impact on the values individuals attribute to work and their work orientation (Grace \& Cramer, 2002; Karl \& Sutton, 1998; Ma \& Schoeneman, 1997; Schreuder \& Theron, 2001). Legal professionals in the larger public sector organisations are a lot more vulnerable today, because of the escalation in retrenchments and layoffs due to increasing competition and restructuring of organisations (Karl \& Sutton; Schreuder \& Theron). In the private sector, too, labour market conditions have been characterized as having too many lawyers competing for too few clients (Abel, 1989, as cited in J. E. Wallace, 1995). These factors may result in employees valuing job security more than intrinsic factors. The legal profession also tends to be a very high paying profession, which might attract individuals who have a higher extrinsic motivation towards work. This may, however, be presumptuous and further research is needed to validate this assumption.

Even though a good income was by far the most valued by legal professionals, intrinsic factors such as 'interesting work' and 'opportunity to learn' were also placed in the top five important factors. These findings seem to highlight the fact that, even though legal professionals tend to have a high extrinsic work orientation, there are various other intrinsic factors that are also valued. Further in-depth research might be needed to gain a better understanding as to why legal professions have this work orientation. In order to answer this question, it is recommended that future research include a qualitative component.

Even though the legal profession as a whole tends to be extrinsically motivated, no differences were found between individuals who have work as a CLI and those who do not, with respect to their work orientation. This finding is in agreement with research done by Gorn and Kanungo (1980) and Starcevich (1973), which found that individuals' work orientation remains the same irrespective of their work 
centrality. However, other research has found that individuals who have work as a CLI prefer jobs with intrinsic factors such as challenge, freedom, participation and personal growth, and that individuals who do not have work as a CLI prefer jobs with extrinsic factors such as high salary and job security (Dubin, Hedley \& Taveggai, 1976; Rabinowitz, 1980, as cited in Roberson, 1990). The fact that no differences were found in the current sample tends to highlight the important impact that the changing world of work has had on the work orientations of individuals.

The finding in the current study of no differences in work orientation between private and public sector legal professionals differs from previous research findings of distinct differences in work orientation between the public and private sector in general (Karl \& Sutton, 1998; Snir \& Harpaz, 2001, as cited in Vigoda, 2002; Weaver \& Franz, 1992). Surprisingly, it was also found that there was no statistically significant difference in the value attributed to income between legal professionals in the public and private sector This is contrary to previous findings, which revealed that private sector employees tend to place a significantly higher value on a good salary or income than employees in the public sector (Karl \& Sutton; Snir \& Harpaz, as cited in Vigoda). This similarity between the private and public sector for the legal profession in particular is not necessarily that unusual, however. A study done by J. E. Wallace (1995) found that legal professionals in public and private sectors both value economic rewards. Thus this similar response across sectors may be due to a common professional identity, regardless of the occupational sector, that reflects a shared work-related value with regards to income.

It was found that most individuals within the sample of legal professionals, regardless of whether they had work as a CLI or whether they worked in the public or private sector, tended to define work in the same way. Most individuals used the economic definition of work (Brief \& Nord, 1990; Dubin, 1992; Watson, 1995). Schreuder and Theron (2001) proposed that individual meanings of work are derived directly or indirectly from socio-cultural influences, for example group affiliation and work experience, and thus it can be argued that because individuals within the legal profession tend to come from the same locale (they all work in the same profession, all work within an organisation, whether private or public, they all get paid, most underwent the same level of training, and they tend to work the same number of hours) they will tend to define and attribute the same meaning to work.

\section{CONCLUSION}

This study investigated whether work constituted a CLI for legal professionals in South Africa. Findings suggest that, for most legal professionals, work did not constitute a CLI. Although work is not central in the lives of these professionals, it was found that it does still play an important role. Structural job characteristics proposed by Dubin, namely autonomy, uncertainty and risk, and personal responsibility, were found to have low predictive value when used to explain the CLIs of legal professionals. Instead it was found that factors such as limited interpersonal relationships and the move towards specialisation in the legal profession provided a better explanation for the CLI choices made by these professionals. Furthermore, contrary to assumptions and previous research, interesting similarities were found between the public and private sector concerning CLI and work orientation. It was also found that individuals in the legal profession tend to have an extrinsic orientation towards work and attribute most value to a good salary or income.

This study has considered many important issues surrounding CLIs and work orientations of professionals. Yet the changing nature of work necessitates continual research into the area and it is hoped that this study may contribute to further understanding of the importance of work in the lives of professionals in South Africa.

\section{REFERENCES}

Argyle, M. (1972). The social psychology of work. London: The Penguin Press.

Aronowitz, S. \& DiFazio, W. (1994). The jobless future: Sci-tech and the dogma of work. Minnesota: University of Minnesota Press.

Baba, V. V. (1989). Central Life Interests and job involvement: An exploratory study in the developing world. International Journal of Comparative Sociology, 30, 182 - 191.

Bridges, W. (1994). JobShift. Reading, Massachusetts: Perseus Books.

Bryan, D. L. (1972). Teachers' views of work as a Central Life Interest and its relationship to student ratings of teachers' effectiveness. Unpublished Doctoral dissertation, Michigan State University.

Dalton, D. R. \& Todor, W. D. (1983). Psychometric properties of the Central Life Interest Inventory. Psychological Reports, 52, $887-891$

Doyle, V. (2001). The A-Z of careers: The South African career encyclopaedia (14th ed.). Cape Town: Don Nelson Publishers.

Dubin, R. (1956). Industrial workers' worlds: A study of the Central Life Interests of industrial workers. Social Problems, 3 , $131-142$

Dubin, R. (1992). Central Life Interests: Creative individualism in a complex world. New Brunswick, New Jersey: Transaction Publishers.

Dubin, R. \& Champoux, J. E. (1977). Central Life Interests and job satisfaction. Organizational Behavior and Human Performance, 18, $366-376$.

Dubin, R., Champoux, J. E., \& Porter, L. W. (1975). Central Life Interests and organizational commitment of blue-collar and clerical workers. Administrative Science Quarterly, 20, 411 421.

England, G. W. \& Misumi, J. (1986). Work centrality in Japan and the United States. Journal of Cross-Cultural Psychology, 17, $399-414$

England, G. W., Ruiz-Quintanilla, S. A. \& Maimer, J. (1995). The meaning of working survey C. Retrieved March 1, 2003, from http://allserv.rug.ac.be/ rclaes/MOW/surv_c_e.pdf

Fink, A. (1995). How to sample in surveys. Thousand Oaks: Sage Publications.

Friedlander, F. (1966). Importance of work versus nonwork among socially and occupationally stratified groups. Journal of Applied Psychology, 50, 437 - 441.

Grace, S. L. \& Cramer, K. L. (2002). Sense of self in the new millennium: Male and female student responses to the TST. Social Behavior and Personality, 30, 271 - 280.

Gorn, G. J. \& Kanungo, R. N. (1980). Job involvement and motivation: Are intrinsically motivated managers more job involved? Organizational Behavior and Human Performance, $26,265-277$.

Henry, G. T. (1990). Practical Sampling. Newbury Park: Sage Publications.

Human, L. H. (1998). My career. South Africa: The Department of Labour.

Karl, K. A. \& Sutton, C. L. (1998). Job values in today's workforce: A comparison of public and private employees. Public Personnel Management, 27, 515 - 528.

Ma, V. \& Schoeneman, T. J. (1997). Individualism versus collectivism: A comparison of Kenyan and American selfconcepts. Basic and Applied Social Psychology, 19, 261 - 273.

Noon, M. \& Blyton, P. (1997). The realities of work. London: Macmillan Press Ltd.

Orzack, L. H. (1959). Work as a Central Life Interest of professionals. Social Problems, 7, 125 - 132 
Rifkin, J. (1995). The end of work: The decline of the global labour force and the dawn of the post-market era. New York: Putnam. Roberson, L. (1990). Functions of work meanings in organizations: Work meanings and work motivation. In A. P. Brief and W. R. Nord (Eds.), Meanings of occupational work: A collection of essays (pp. 107 - 134). Massachusetts: Lexington Books.

Schreuder, A. M. G. \& Theron, A. L. (2001). Careers: An organizational perspective (2nd ed.). Lansdowne: Juta.

Starcevich, M. M. (1973). The relationship between the Central Life Interests of first-line managers, middle managers, and professional employees and job characteristics as satisfiers and dissatisfiers. Personnel Psychology, 26, 107 - 115.

Statt, D. A. (1994). Psychology and the world of work. London: Macmillan Press.

Vecchio, R. P. (1980). The function and meaning of work and the job: Morse and Weiss (1955) revisited. Academy of Management Journal, 23, 361 - 367.
Vigoda, E. (2002). Public administration - the new generation. New York: Marcel Dekker.

Wallace, J. E. (1995). Organizational and professional commitment in professional and nonprofessional organizations. Administrative Science Quarterly, 40, 228 255.

Wallace, M. (1989). Brave new workplace: Technology and work in the new economy. Work And Occupations, 16, $363-391$.

Wallis, T. \& Price, L. (2003). The relationship between workfamily conflict and Central Life Interests amongst single working mothers. South African Journal of Industrial Psychology, 29, 26 - 31.

Watson, T. J. (1995). Sociology, work and industry (3 ${ }^{\text {rd }}$ ed.). London: Routledge

Weaver, C. N. \& Franz, R. S. (1992). Work related attitudes of entrepreneurs, public, and private employees. Psychological Reports, 70, 387 - 390. 